\title{
Peningkatan Kualitas Telur Itik Pitalah dengan Pemberian Pakan Tepung Daun Lamtoro (Leucaena leucochepala) yang Difermentasi dengan Bacillus laterosporus dan Trichoderma viride
}

\section{The Quality of Pitalah Duck Eggs Consumed Fermented Leucaena Leaf Meal in the Ration.}

\author{
N. Yessirita ${ }^{1}$, M. H. Abbas ${ }^{2}$, Y. Heryandi ${ }^{2}$, dan A. Dharma ${ }^{3}$ \\ ${ }^{1}$ Akademi Pembangunan Pertanian Sumbar, Padang, Indonesia \\ ${ }^{2}$ Fakultas Peternakan Universitas Andalas, Padang, Indonesia \\ ${ }^{3}$ Fakultas Kimia FMIPA Universitas Andalas, Padang, Indonesia \\ e-mail : nitayessirita@yahoo.com \\ (Diterima: 11 Oktober 2014; Disetujui: 15 Januari 2015)
}

\begin{abstract}
ABSTRAK
Tujuan dari penelitian untuk mengetahui pengaruh fermentasi makanan daun lamtoro dalam ransum itik Pitalah. Desain penelitian menggunakan rancangan acak kelompok (RAK) dengan 7 perlakuan, 3 ulangan dan setiap ulangan terdiri dari 6 petelur bebek. Perlakuan penelitian ini adalah R0 (kontrol), R1 (10\% tepung daun lamtoro tanpa fermentasi), R2 (10\% TDL fermentasi dengan Bacillus laterosporus), R3 (20\% TDL fermentasi dengan Bacillus laterosporus), R4 (10\% TDL fermentasi dengan Trichoderma viride) dan R5 (20\% TDL fermentasi dengan Trichoderma viride) dan R6 (10\% TDL Fermentasi dengan Bacillus laterosporus $+10 \%$ TDL fermentasi dengan Trichoderma viride). Parameter yang diamati seperti: lemak, kolesterol dan warna kuning telur. Hasil penelitian menunjukkan bahwa perlakuan ransum berbeda sangat nyata $(\mathrm{P}<0,01)$ untuk kolesterol dan warna kuning telur tetapi berbeda nyata $(\mathrm{P}<0,05)$ untuk lemak kuning telur. Penggunaan produk daun lamtoro fermentasi dengan Trichoderma viride dan Bacillus laterosporus sebanyak $20 \%$ di ransum itik Pitalah dan perlakuan R3 penurunan lemak $(18,50 \%)$, kolesterol kuning telur $(42,00 \mathrm{mg} / \mathrm{dl})$ dan peningkatan warna kuning telur 12,67. Perlakuan R3 lebih baik daripada kontrol ransum dan ransum lain dan juga bisa meningkatkan kinerja itik Pitalah.
\end{abstract}

Kata kunci: tepung daun lamtoro, Bacillus laterosporus, Trichoderma viride, itik Pitalah

\section{ABSTRACT}

The research aimed at determining the effect of fermented leucaena leaf meal in the ration of Pitalah ducks. The experiment used randomized completely block of design (RCBD) with 7 treatments and 3 replications for 6 heads of laying duck. The treatments contained following features; RO (control), R1(10\% leucaena leaf meal without fermentation), $R 2$ (10\% leucaena leaf meal fermented by Bacillus laterosporus), R3(20\% leucaena leaf meal fermented by Bacillus laterosporus), R4 (10\% leucaena leaf meal fermented by Trichoderma viride), $R 5$ (20\% leucaena leaf meal fermented by Trichoderma viride), R6 (10\% leucaena leaf meal fermented by Bacillus laterosporus $+10 \%$ leucaena leaf meal fermented by Trichoderma viride). Measured parameter included yolk fatty, yolk cholesterol and yolk color. The results showed that the ration treatment affected at highly significant $(P<0.01)$ for yolk cholesterol and yolk color but influenced at significantly $(P<0.05)$ for yolk fatty treatment. The use of $20 \%$ of fermented leucaena leaf with Trichoderma viride and Bacillus laterosporus in Pitalah ducks rations and $R 3$ treatment decreased fatty yolk (18.50\%), yolk cholesterol $(42.00 \mathrm{mg} / \mathrm{dl})$ and in contrast increase yolk color 12.67. Treatment $R 3$ was better compared to control ration and another treatments as well as improve the performance of Pitalah ducks.

Keywords: leucaena leaf meal, Bacillus laterosporus, Trichoderma viride, Pitalah ducks 


\section{PENDAHULUAN}

Ternak unggas berguna memenuhi kebutuhan pangan hewani (protein) yang mudah dan cepat, sebagai sumber pendapatan rumah tangga dan kesejahteraan keluarga untuk mengurangi angka kemiskinan, merupakan pilihan yang tepat karena selain cepat menghasilkan daging juga menghasilkan telur. Diantara ternak lokal unggas yang berpotensi adalah itik.

Keberadaan itik Pitalah sebagai unggas asli dan aset biologis (plasma nutfah) Sumatera Barat, kini populasi dan keaslian genetiknya semakin berkurang. Penyebab utama dari permasalahan tersebut adalah sistem budidaya pemeliharaan yang masih tradisional dan ketersediaan pakan berkualitas dan murah yang sulit didapat, selain itu kebanyakan masyarakat petani/peternak lokal masih berjuang dalam meningkatkan kesejahteraan hidupnya. Direktorat Jendral Peternakan (2012), populasi itik Sumatera Barat, populasi itik tahun 2010 adalah 1.147.848 ekor sedangkan pada tahun 2011 populasi itik menurun 1.123.264 ekor atau menurun 2,14\%. Menurut Kementan (2011) tentang penetapan rumpun (galur ternak) lokal, bahwa itik Pitalah merupakan salah satu kekayaan sumber daya genetik ternak Indonesia yang perlu dilindungi dan dilestarikan.

Salah satu usaha penting yang dapat dilakukan dalam meningkatkan kelestarian dan populasi itik Pitalah adalah melalui pakan. Diversifikasi pakan dengan memanfaatkan pakan lokal yang berpotensi baik adalah lomtoro. NAS (1984), menyatakan lamtoro menghasilkan bahan kering sebesar 6-8 ton/hektar/tahun atau setara 20-80 ton bahan segar/hektar/tahun. Selain itu kandungan protein kasar hijauan lamtoro cukup tinggi yakni berkisar 25-30\%. Ditambahkan Garcia, et al. (1996), kandungan protein lamtoro mencapai $29,20 \%$ dan $\beta$-Karotene mencapai $237,50 \mathrm{mg} / \mathrm{kg}$. Komposisi asam amino daun lamtoro hampir seimbang dengan tepung ikan, kecuali lisin dan methionin yang lebih rendah, sedangkan jika dibandingkan dengan bungkil kedelai kecuali asam glutamate, asam amino lainnya cukup seimbang. Tepung daun lamtoro (TDL) merupakan sumber vitamin A dengan kandungan $\beta$-Karotene relatif tinggi yang dapat menurunkan kolesterol. Kandungan xantofil yakni sebesar $888,72 \mathrm{mg} / \mathrm{kg}$ BK, juga lebih tinggi dari kandungan xantofil jagung kuning dan daun alfalfa yang hanya mengandung $300 \mathrm{mg} / \mathrm{kg}$ BK. Xantofil ini berperan sebagai sumber pigmentasi pada kulit dan kuning telur (Laconi dan Widiyastuti, 2010).

Selain mengandung anti nutrisi, lamtoro juga mengandung serat kasar yang cukup tinggi. Menurut Garcia, et al., (1996), serat kasar yang terkandung pada hijauan (daun dan ranting) sangat tinggi berkisar 35,00\% sedangkan pada tepung daun turun menjadi 19,20\%. Metode fisik dan kimia yang telah dilakukan untuk menurunkan zat anti nutrisi mimosin dalam daun lamtoro adalah dengan pemanasan, penambahahan garam sulfat, penambahan senyawa analog mimosin, pencucian, mendapatkan varietas baru yang rendah kandungan mimosinnya. Metode lain secara biologi dengan cara fermentasi dapat menurunkan kadar mimosin lamtoro. Metoda biologi yang telah dicobakan oleh Komari (1994) terhadap biji lamtoro adalah dengan merebus dan membuang kulitnya dan selanjutnya difermentasi dengan kapang Rhizopus oligoporus selama 48 jam dapat mereduksi kadar mimosin sebanyak dari $10.600 \mathrm{mg}$ menjadi $190 \mathrm{mg}$. Dalam hal ini dikakukan penelitian dengan menggunakan mikroorganisme yang dapat dimanfaatkan dalam proses fermentasi diantaranya adalah bakteri Bacillus laterosporus dan kapang Trichoderma viride. Penggunaan produk fermentasi tepung daun lamtoro menggunakan kedua mikroorganisme selulolitik ini telah dapat meningkatkan performa itik Pitalah (Yessirita et al., 2013).

Upaya untuk menurunkan kandungan kolesterol telur dan meningkatkan kualitas telur itik Pitalah, dapat dilakukan dengan memberikan produk fermentasi. Penggunaan produk fermentasi menggunakan inokulum 
Bacillus laterosporus dan Trichoderma viride pada substrat lamtoro yang mengandung $\beta$ karoten tinggi yang dapat menurunkan kolesterol, diharapkan akan dapat memenuhi permintaan konsumen, yakni telur itik rendah kolesterol dan memiliki kuning telur kuning kemerahan.

\section{METODE}

Penelitian ini menggunakan 126 ekor itik Pitalah betina berumur 5,5 - 6 bulan, terdiri dari 21 kandang baterai induvidual yang terbuat dari bambu yang berukuran 100x100x50 $\mathrm{cm}^{3}$, masing-masing dilengkapi tempat makan dan minum. Kandungan zat-zat makanan terdiri dari jagung kuning, tepung ikan, bungkil kedelai, dedak, minyak kelapa, mineral bebek, $\mathrm{CaCO} 3$ dan tepung daun lamtoro yuang difermentasi (dengan Bacillus laterosporus dan Trichoderma viride) dan tanpa fermentasi seperti terlihat pada Tabel 1, kandungan zat-zat makanan (\%) dan kandungan energi metabolisme (Kcal $/ \mathrm{kg}$ ) bahan penyusun ransum. Komposisi zat-zat makanan disusun dan diformulasi berdasarkan NRC (1994) disusun dengan isoprotein $(16,5 \%)$ da isoenergi $(2850 \mathrm{Kcal} / \mathrm{kg})$ dan analisa kandungan zat-zat makanan dilakukan di labor Nutrisi non ruminansia dan penelitian dilakukan di kandang UPT Fakultas Peternakan Universitas Andalas Padang.

Percobaan penelitian ini terdiri dari 7 perlakuan dan 3 ulangan dan masing-masing unit percobaan terdiri dari 6 ekor itik. Penelitian ini menggunakan Rancangan Acak Kelompok (RAK) menurut Steel dan Torrie (1995). Data dianalisis menggunakan program SAS (1996). Perlakuan terdiri dari R0 (ransum kontrol), R1 (10\% TDL tanpa fermentasi), R2 (10\% TDL fermentasi dengan Bacillus laterosporus), R3 (20\% TDL fermentasi dengan Bacillus laterosporus), R4 (10\% TDL fermentasi dengan Trichoderma viride) dan R5 $(20 \%$ TDL fermentasi dengan Trichoderma viride) dan R6 (10\% TDL Fermentasi dengan Bacillus laterosporus + 10\% TDL fermentasi dengan Trichoderma viride). Lamtoro diambil daunnya kemudian dipanaskan dan dikeringkan pada suhu $60^{\circ} \mathrm{C}$ selama 24 jam, kemudian digiling. Substrat yang digunakan terdiri dari tepung daun lamtoro dicampur dengan aquades 80\% kemudian diautoclav selama 15 menit 1 Atm, didinginkan pada suhu kamar, kemudian

Tabel 1. Kandungan zat-zat makanan (\%) dan energi metabolisme (Kkal/kg) bahan penyusun ransum.

\begin{tabular}{lcccccc}
\hline Bahan pakan & PK & Lemak & SK & Ca & P & ME (Kkal/kg) \\
\hline Jagung giling & 9,86 & 2,33 & 2,06 & 0,20 & 0,28 & $3300,00^{\mathrm{b}}$ \\
Dedak halus & 8,37 & 6,91 & 13,05 & 0,21 & 0,90 & $1896,00^{\mathrm{b}}$ \\
Bungkil kedelai & 41,74 & 1,91 & 4,96 & 0,32 & 0,29 & $2720,00^{\mathrm{b}}$ \\
Tepung ikan & 48,32 & 3,78 & 5,02 & 5,50 & 2,80 & $2440,00^{\mathrm{b}}$ \\
TDLFB & 30,09 & 2,03 & 12,24 & 1,91 & 0,25 & 2524,74 \\
TDLFT & 32,67 & 2,37 & 12,52 & 3,22 & 0,26 & 2504,34 \\
Lamtoro TF & 22,69 & 1,55 & 16,77 & 4,48 & 0,25 & 1901,87 \\
Minyak kelapa & - & 100,00 & - & - & - & $8600,00^{\mathrm{b}}$ \\
CaCo3 & - & - & - & 88,00 & - & - \\
Mineral itik & - & - & - & 48,72 & 12,50 & - \\
\hline KaCo & & & & & &
\end{tabular}

Keterangan: b $\quad=$ Wahju (1997)

TDLFBL $=$ Tepung daun lamtoro fermentasi bacillus laterosporus

TDLFTV $=$ Tepung daun lamtoro fermentasi trichoderma viride 
Tabel 2. Komposisi dan kandungan zat-zat makanan (\%) serta energi metabolisme $(\mathrm{Kkal} / \mathrm{kg}$ ) ransum penelitian.

\begin{tabular}{|c|c|c|c|c|c|c|c|}
\hline \multirow{2}{*}{ Bahan Pakan } & \multicolumn{7}{|c|}{ Ransum Perlakuan (\%) } \\
\hline & R0 & R1 & R2 & R3 & R4 & R5 & R6 \\
\hline Jagung giling & 49,00 & 49,25 & 48,00 & 46,50 & 48,00 & 48,00 & 46,50 \\
\hline Dedak halus & 25,75 & 19,00 & 23,00 & 20,75 & 23,00 & 20,00 & 21,00 \\
\hline B. kedelai & 10,00 & 8,00 & 6,00 & 2,50 & 6,25 & 2,50 & 2,50 \\
\hline T. ikan & 11,00 & 9,25 & 9,00 & 6,50 & 8,00 & 5,25 & 6,00 \\
\hline Lamtoro TF & 0,00 & 10,00 & 0,00 & 0,00 & 0,00 & 0,00 & 0,00 \\
\hline TDLFB & 0,00 & 0,00 & 10,00 & 20,00 & 00,00 & 00,00 & 10,00 \\
\hline TDLFT & 0,00 & 0,00 & 00,00 & 00,00 & 10,00 & 20,00 & 10,00 \\
\hline M. kelapa & 2,00 & 2,25 & 2,00 & 2,00 & 2,00 & 2,00 & 2,00 \\
\hline $\mathrm{CaCO}_{3}$ & 0,75 & 1,25 & 1,00 & 1,25 & 1,00 & 1,00 & 0,75 \\
\hline Mineral itik & 1,50 & 1,00 & 1,00 & 0,50 & 1,50 & 1,50 & 1,25 \\
\hline Total & 100,00 & 100,00 & 100,00 & 100,00 & 100,00 & 100,00 & 100,00 \\
\hline $\mathrm{Pk} \quad(\%)$ & 16,48 & 16,52 & 16,52 & 16,52 & 16,50 & 16,52 & 16,56 \\
\hline Lemak $(\%)$ & 5,53 & 5,37 & 5,37 & 5,22 & 5,37 & 5,22 & 5,25 \\
\hline $\mathrm{Sk} \quad(\%)$ & 5,42 & 6,03 & 5,96 & 6,56 & 5,97 & 6,49 & 6,59 \\
\hline$(\%)$ & 2,48 & 2,45 & 2,47 & 2,45 & 2,54 & 2,47 & 2,51 \\
\hline$(\%)$ & 0,79 & 0,74 & 0,76 & 0,71 & 0,79 & 0,71 & 0,70 \\
\hline $\mathrm{ME}$ & 2842,12 & 2837,10 & 2851,35 & 2854,72 & 2838,51 & 2856,17 & 2845,22 \\
\hline Metionin (\%) & 0,50 & 0,45 & 0,44 & 0,37 & 0,42 & 0,35 & 0,36 \\
\hline Lysin (\%) & 0,79 & 0,78 & 0,76 & 0,72 & 0,70 & 0,61 & 0,67 \\
\hline
\end{tabular}

Keterangan : Dihitung berdasarkan Tabel 1.

diinokulasi dengan $6 \%$ Bacillus laterosporus difermentasi selama 24 jam pada suhu $37^{\circ} \mathrm{C}$ dalam inkubator dengan ketebalan susbtrat 2 $\mathrm{cm}$ dan untuk substrat yang diinokulasi dengan $7 \%$ Trichoderma viride yang difermentasi selama 7 hari dengan ketebalan substrat $2 \mathrm{~cm}$ (Yessirita et al., 2012). Produk fermentasi dikeringkan pada suhu $60^{\circ} \mathrm{C}$ selama 24 jam. Parameter yang diukur adalah: lemak, kolesterol dan skor warna kuning telur. Komposisi dan kandungan zat-zat makanan (\%) serta energi metabolisme ransum penelitian dapat dilihat pada Tabel 2.

\section{HASIL DAN PEMBAHASAN}

Rataan kualitas telur (lemak, skor warna kuning telur dan kandungan kolesterol kuning telur) itik yang mendapat ransum perlakuan selama penelitian dapat dilihat pada Tabel 3 .

\section{Lemak kuning telur itik (\%)}

Hasil analisis ragam memperlihatkan bahwa pemberian TDL kontrol, produk sebelum fermentasi dan sesudah fermentasi dengan Bacillus laterosporus dan Trichoderma viiride maupun campurannya sampai level $20 \%$ memberikan pengaruh yang sangat nyata $(\mathrm{P}<0,01)$ terhadap lemak kuning telur itik. Berdasarkan uji DMNRT terlihat pada perlakuan kontrol berbeda nyata dengan perlakuan TDL sebelum dan sesudah fermentasi maupun campurannya. Di sini terlihat bahwa lamtoro sebelum fermentasi mengandung $\beta$-Karoten yang cukup tinggi dibandingkan ransum kontrol yang mengandung $\beta$ Karoten yang lebih rendah dibandingkan TDL tanpa fermentasi dan produk fermentasi. Vitamin A yang memiliki komponen aktif Betakaroten, kemungkinan mampu mengham- 
Vol. 17 (1)

Tabel 3. Pengaruh perlakuan terhadap kualitas telur itik selama penelitian

\begin{tabular}{rccc}
\hline Perlakuan & $\begin{array}{c}\text { Lemak Kuning Telur } \\
(\%)\end{array}$ & $\begin{array}{c}\text { Kolesterol Kuning Telur } \\
(\mathrm{mg} / \mathrm{dl})\end{array}$ & Warna Kuning Telur \\
\hline R0 & $24,23^{\mathrm{a}}$ & $164,00^{\mathrm{a}}$ & $8,67^{\mathrm{e}}$ \\
R1 & $20,52^{\mathrm{b}}$ & $109,00^{\mathrm{b}}$ & $11,33^{\mathrm{cd}}$ \\
R2 & $18,69^{\mathrm{b}}$ & $79,00^{\mathrm{c}}$ & $12,00^{\mathrm{abc}}$ \\
R3 & $18,50^{\mathrm{b}}$ & $42,00^{\mathrm{d}}$ & $12,67^{\mathrm{a}}$ \\
R4 & $18,83^{\mathrm{b}}$ & $87,00^{\mathrm{c}}$ & $11,67^{\mathrm{bc}}$ \\
R5 & $18,52^{\mathrm{b}}$ & $50,00^{\mathrm{d}}$ & $12,33^{\mathrm{ab}}$ \\
R6 & $18,74^{\mathrm{b}}$ & $83,00^{\mathrm{c}}$ & $10,67^{\mathrm{d}}$ \\
\hline SE & 0,93 & 3,02 & 0,28 \\
\hline
\end{tabular}

Ket : Superskrip yang berbeda pada kolam yang sama menunjukkan pengaruh yang berbeda nyata $(\mathrm{P}<0,05)$ antar perlakuan.

bat oksidasi lipid dan Low Density Lipoprotein (LDL) (Sweetman, 2007). Terhambatnya proses oksidasi lipid menyebabkan penghambatan proses pembentukan asetilKoA sebagai prekursor awal dari biosintesis kolesterol di hati.

Menurut Yuniastuti (2002) bahwa secara umum perlemakkan sangat dipengaruhi oleh nutrisi ransum yang dikonsumsi. Razdan dan Petterson (I994) menyatakan pencernaan enzimatis dilakukan cairan pankreas, empedu di usus dalam keadaan basa. Sementara dengan meningkatnya pemakaian TDL dalam ransum perlakuan dan dalam saluran pencernaan, mengakibatkan pencernaan tidak sempurna karena terkelupasnya mukosa usus dan mengganggu absorbsi, keadaan ini memicu $\mathrm{pH}$ percernaan menjadi terkendali, dan menekan aktivitas sintesa enzim lemak sehingga proses lipogenesis terlambat, dengan demikian maka lemak yang ditransportasi kejaringan relatif sedikit, sehingga kadar lernak dalam tubuh rendah, seperti lemak abdomen dan lemak karkas. Bintang et al., (1998) menyatakan lemak tubuh dipengaruhi serat kasar ransum, hal ini sependapat dengan Miettinen (1987) keberadaan serat kasar dalam ransum mampu mengikat asam empedu, asam empedu berfungsi untuk mengemulsi makanan berlemak sehingga mudah dihidrolisis oleh enzim lipase. Bila sebagian besar asam empedu tersebut diikat oleh serat kasar maka emulsi partikel lipida yang terbentuk lebih sedikit sehingga aktivitas enzim lipase berkurang, akibatnya akan banyak lipida dikeluarkan bersama kotoran karena tidak diserap tubuh, akhirnya jaringan tubuh akan sedikit mengandung lipida jadi secara langsung dapat mengganggu absorsi lipida dan mempercepat gerak makanan dalam usus. Ravindran dan Blair (1992) serta Amrullah (2003) menyatakan bahwa daya cerna dipengaruhi ransum mengandung serat.

\section{Kolesterol kuning telur itik (mg/dl)}

Hasil analisis ragam memperlihatkan bahwa pemberian TDL produk fermentasi dengan Bacillus laterosporus (R3) dan Trichoderma viiride (R5) sampai level $20 \%$ memberikan pengaruh yang sangat nyata $(\mathrm{P}<$ 0,01) terhadap kolesterol kuning telur ayam. Berdasarkan uji DMRT (Tabel 23), terlihat pada perlakuan dengan penggunaan sampai $20 \%$ produk fermentasi berpengaruh sangat nyata $(\mathrm{P}<0,01)$ dan lebih tinggi dari pada perlakuan dengan penggunaan $0 \%, 10 \%$ tanpa dan sesudah fermentasi. Semakin meningkat level pemberian produk fermentasi semakin menurun kolesterol telur itik dan kembali menurun pada perlakuan R6 (gabungan produk fermentasi).

Syamsuhaidi (1997) melaporkan, bahwa semakin tinggi pemberian duckweed (20-40\%) sebagai sumber serat pada broiler umur 3-8 minggu cenderung menghasilkan kolesterol daging yang semakin rendah. Terjadinya penurunan kolesterol, karena serat kasar mampu memperbaiki ekosistem mikroflora saluran pencernaan, karakteristik pakan menjadi bulky dan volomunis. Akibatnya, gerakan peristaltik usus meningkat, rate of 
passage pakan semakin cepat, transit pakan pada saluran pencernaan singkat, sehingga membatasi penyerapan energi hasil fermentasi prebiotik oleh bakteri probiotik di dalam ventrikulus dalam bentuk asam asetat (asetilKoA). Asam asetat berfungsi sebagai perkusor dan disimpan di hati (Montgomery, 1993). Selain itu khasiat lain dari produk fermentasi, seperti yang dilaporkan oleh Tanaka et al. (1992) bahwa penggunaan bahan pakan produk fermentasi ternyata dapat menekan aktivitas enzim 3-hydroxy-3-methylglutaryl Co-A reduktase yang berfungsi untuk mensintesis kolesterol dalam hati. Enzim ini berperan dalam pembentukan mevalonat dalam proses sintesis kolesterol sehingga tidak terbentuk kolesterol.

Pada penelitian ini diketahui bahwa lamtoro mengandung $\beta$-karoten. $\beta$-karoten adalah precusor vitamin A. Vitamin A yang memiliki komponen aktif betakaroten, kemungkinan 1) mampu menghambat oksidasi lipid dan Low Density Lipoprotein (LDL) (Sweetman, 2007), dan 2) menurunkan nicotinamide adenine dinucleotedhidrogenase serta nicotinamide adeninedinucleoted phosphate hidrogenase sebagai sumber energi yang diperlukan pada setiap tahapan proses biosintesis kolesterol (Naim, 1992; Harper, 2001). Terhambatnya proses oksidasi lipid menyebabkan penghambatan proses pembentukan asetil-KoA sebagai prekursor awal dari biosintesis kolesterol di hati, sehingga kolesterol yang ditransfer pada serum dan juga dalam telur akan menurun. Pernyataan ini didukung oleh Naim (1992), bahwa kolesterol yang terdapat pada kuning telur hanya diperoleh dari hasil sintesis kolesterol di hati. Hasil penelitian ini sesuai dengan pendapat Sitepoe (1993), bahwa vitamin A bersama karoten mampu menurunkan kolesterol telur ayam. Ditambahkan Sutama (2008), komponen aktif betakaroten pada daun pepaya dapat menurunkan kolesterol dan sebagai antioksidan.

Pemberian produk fermentasi ternak itik umur 24-33 minggu pada penelitian ini sampai level $20 \%$ dapat menurunkan kolesterol kuning telur $164 \mathrm{mg} / \mathrm{dl}$ (ransum kontrol) menjadi $42 \mathrm{mg} / \mathrm{dl}$ (R3) produk fermentasi dengan Bacillus laterosporus dan $50 \mathrm{mg} / \mathrm{dl}$ (R5) produk fermentasi dengan Trichoderma viride. Angka ini lebih rendah dari hasil yang didapatkan oleh Saerang (1997) bahwa kandungan kolesterol per gram dari telur ayam muda yang berumur 24 minggu kadar kolesterol telurnya $121 \mathrm{mg} /$ butir, sedangkan ayam yang berumur 68 minggu kadar kolesterolnya $313 \mathrm{mg} / \mathrm{butir}$, dengan berat telur 50-70 gram dan juga kolesterol penelitian ini juga lebih rendah dibandingkan dengan penelitian Wiradimaja (2007), kandungan kolesterol kuning telur hasil pada puyuh dengan penambahan $15 \%$ daun katuk yang mengandung $\beta$ karoten 104,61 ppm menurunkan kandungan kolesterol kuning telur dari 241 menjadi 199,2 ppm. Meningkatnya kembali kadar kolesterol kuning telur pada perlakuan R6 (gabungan produk fermentasi bakteri dan jamur) karena ke 2 mikroba dari Bacillus laterosporus dan Trichoderma viride bersifat competitive exclution (saling meniadakan karena tidak sejenis) dan tidak bisa bekerjasama menghambat enzim Hydroxi Metyl Glutaryil-KoA reduktase (HMG-KoA reduktase) yang berperan dalam pembentukan mevalonat dalam proses sintesis kolesterol sehingga terbentuknya kolesterol. Sesuai dengan Voet et al. (1999) dan Sudha et al. (2009) menyatakan penurunan kolesterol terjadi karena senyawa yang dihasilkan mikrobia berkompetisi dengan HMG-KoA untuk berikatan dengan enzim HMG-KoA reduktase. Enzim ini berperan dalam pembentukan mevalonat dalam proses sintesis kolesterol sehingga tidak terbentuk kolesterol.

\section{Warna kuning telur itik}

Hasil analisis ragam menunjukkankan bahwa pemberian ransum kontrol, TDL produk sebelum dan sesudah fermentasi dengan Bacillus laterosporus dan Trichoderma viiride maupun campurannya sampai level 20\% memberikan pengaruh yang sangat nyata $(\mathrm{P}<0,01)$ terhadap warna kuning telur ayam. Penggunaan 20\% TDL produk fermentasi dengan Bacillus laterosporus dan Trichoderma viiride lebih tinggi dari pada perlakuan lain. Hal ini mengindikasikan bahwa pigmen penguning 
yang terkandung pada tepung daun lamtoro sangat berperan dalam meningkatkan indeks warna kuning telur sehingga dengan bertambahnya level pemberian TDL maka meningkat pula indeks warna kuning telur. Ini berarti bahwa tepung daun lamtoro produk fermentasi sangat berpotensi untuk meningkatkan kepekatan warna kuning telur. Hasil penelitian ini sejalan dengan yang dilaporkan oleh Lokapirnasari et al. (2001), bahwa warna kuning telur ayam buras yang diberi daun pepaya $1-2 \%$ pada ransum basal lebih pekat daripada yang tidak diberi daun pepaya. Warna kuning telur ayam akan makin pekat dengan meningkatnya kadar daun pepaya karena adanya vitamin A dan betakaroten (pro-vitaminA). Vitamin A dan $\beta$-karoten akan disimpan dalam jaringan lemak di seluruh tubuh yang menyebabkan warna kekuningan pada lapisan jaringan lemak (Linder, 1992). Ditambahkan pula bahwa, vitamin A berperan dalam pewarnaan kuning telur, kaki, lemak maupun kulit unggas (March et al., 1984).

Tingginya warna kuning telur itik (kuning orange) pada perlakuan TDL produk fermentasi berkaitan dengan kandungan $\beta$ karoten baik sebelum difermentasi dan meningkat setelah difermentasi yaitu kandungan $\beta$-karoten sebelum difermentasi adalah 972,75 ppm dan setelah difermentasi dengan Bacillus laterosporus meningkat menjadi 1915,48 ppm dan dengan Trichoderma viiride meningkat 1643,55 ppm. Semakin meningkatnya level penggunaan produk TDL fermentasi dalam ransum mengakibatkan kandungan karotenoid juga semakin meningkat. Ini disebabkan sumbangan kandungan karotenoid yang berwarna merah yang menyebabkan warna kuning telur itik yang dihasilkan juga meningkat, kemungkinan lain proses fermentasi menyebabkan terurainya pigmentasi TDL. Perlakuan R6 (gabungan produk fermentasi $10 \%$ bakteri Bacillus laterosporus dan 10\% Trichoderma viride), dimana indeks warna kuning telur menurun dibandingkan produk fermentasi, hal ini diprediksi senyawa organik pemberi warna pada kuning telur (pigmen karotenoid) terdiri dari atom-atom dan ikatan-ikatan yang kaya elektron. Atom dan elektron tersebut tidak bisa berinteraksi karena dipengaruhi oleh ion $\mathrm{Na}+$ dan ion $\mathrm{Cl}$ - yang berbeda dan mikroba yang juga berbeda jenisnya, sehingga interaksi pigmen asal xantofil dan karotenoid mereka tidak dapat menyebabkan perubahan intensitas penyebab warna kuning telur, akibatnya aktivitas kedua mikroba tidak sinergis dalam meningkatkan warna kuning telur.

Warna kuning telur itik yang terbaik pada penelitian ini, (umur 24-33 minggu) adalah 12,67. Skor warna kuning telur penelitian ini lebih tinggi dibandingkan penelitian yang dilakukan Wiradimadja et al. (2007) dengan penambahan $15 \%$ daun katuk mengandung $\beta$-karoten 104,61 ppm atau 10,46 $\mathrm{mg} / 100 \mathrm{~g}$ dapat menghasilkan skor warna kuning telur 11,17. Nilai skor warna kuning telur penelitian ini berada dalam kisaran warna kuning telur yang baik dan disukai konsumen, ditambahkan oleh Sudaryani (2003), bahwa warna kuning telur yang baik berada pada kisaran 9,00 - 12,00.

\section{KESIMPULAN}

Berdasarkan hasil penelitian dapat diambil kesimpulan bahwa penggunaan produk fermentasi tepung daun lamtoro (TDLF) dengan Bacillus laterosporus sebanyak 20\% (perlakuan R3) dalam ransum dapat menurunkan lemak dan kolesterol kuning relur serta dapat meningkatkan warna kuning telur. Pada penelitian ini diperoleh lemak kuning telur 18,50\%, kolesterol kuning telur 42,00 mg/dl dan skor warna kuning telur 12,67 .

\section{DAFTAR PUSTAKA}

Amrullah I.K. 2003. Nutrisi ayam petelur. Lembaga Satu Gunung Budi Kompleks IPB Baranang siang Bogor.

Bintang, I.A.K., A.P. Sinurat, T. Murtisari, 1998. Penggunaan bungkil inti sawit dan produk fermentasinya dalam ransum itik sedang bertumbuh. J. llmu Ternak dan Veteriner 4(3): 179- 184. 
Direktorat Jendral Peternakan. 2012. Populasi itik menurut provinsi. Jakarta

Gracia, G.W., T.U. Ferguson., F.A. Neckles and K.A.E. Archibald. 1996. The Nutritive value and forage productive of Leucaena leucochepala. Anim. Feed Sci. Technol. 60: 29 - 41 .

Harper. 2001. Biokimia. Edisi 25. Penerbit Buku Kedokteran EGC, Jakarta.

Keputusan Menteri Pertanian Republik Indonesia, 2011. Penetapan rumpun itik pitalah. Nomor 2923/kpts /ot.140/6/2011. Jakarta.

Komari. 1994. Detoksifikasi biji lamtoro gung. Jurnal Hayati. 1(2) : 47 - 50.

Laconi, E.B. dan T. Widiyastuti. 2010. Kandungan xanthofil daun lamtoro (Leucaena leucochepala) hasil detoksifikasi mimosin secara fisik dan kimia. Jurnal Media Peternakan. 33 (1) : 50 54

Linder, M.C. 1992. Biokimia Nutrisi dan Metabolisme (Terjemahan: Aminuddin Parakkasi). Jakarta: Penerbit Universitas Indonesia

Lokapirnasari, W.P., H. Sutyono, T. Nuhayati, M. Lamid. 2001. Prospek pemanfaatan daun pepaya untuk meningkatkan produksi telur, warna kuning telur dan konsumsi pakan pada ayam buras. Jurnal Penelitian Medika Eksata 2: 1-8.

March, B.E., E.A. Richard, L.S. Jensen, D. Polin, J.L. Sell, P.E. Waibel, P.W. Waldroup. 1984. Nutrition Requirement of Poultry. 8th rev. Ed. Washington DC: National Academy Press.

Miettinen, T.A. 1987. Dietary fiber and lipids. Journal Animal Science 45 : 1237-1242.

Montgomery, R., R.1. Oryer, T.W. Conway and A.A. Specttor. 1993. Biochemistry, A Case Oriented Approach. The CV Moshby Company, St Louis, Tooronto London.
Naim, R. 1992. Mekanisme deposito kolesterol dalam yolk. Poult Indonesia 143: 8

National Academy of Sciences. 1984. Leucaena : Promissing Forage and Tree Crop for the Tropics. $2^{\text {nd }}$ edition. National Academy of Sciences, Washington.

Ravindran, V. dan R. Blair. 1992. Feed resources for poultry production in Asia and the Pacific. 11.Plant orolein sources. Poultrv Science 48 : 206 - 231.

Razdan, A. and D. Pattersson, 1994. Effect of feeding restriction and meal pattern of sugar beetcontaining and control diet on nutrient digestibility, plasma lipid concentrations and postrandial triacylglycerol response in broiler chickens. British Journal Nutrition. $71: 349-400$.

SAS Institute. 1996. The SAS® System for Windows. Release 6.12. SAS Inst., Inc, Cary, NC.

Saerang, J.L.P. 1997. Pengaruh minyak nabati dan lemak hewani dalam ransum puyuh petelur terhadap performans, daya tetas, kadar kolesterol telur, dan plasma darah. Pascasarjana Universitas Gadjah Mada, Yogyakarta.

Syamsuhaidi. 1997. Penggunaan duckweed (family lemnaceae) sebagai pakan serat sumber protein dalam ransum ayam pedaging. Program Pascasarjana, Institut Pertanian Bogor.

Sitepoe, M. 1993. Kolesterol fobia belum saatnya berkembang di Indonesia. Infovet 005:14-15

Steel, R.G.D. dan J.H. Torie. 1995. Prinsip dan Prosedur Statistika. Suatu Pendekatan Iometrik. PT. Gramedia Pustaka Utama, Jakarta.

Sudaryani, T. 2003. Kualitas Telur. Penebar Swadaya, Jakarta.

Sweetman S. 2007. The Complete Drug Reference. London: Pharmaceutical Press, 
Sudha, M.R., C. Prashant, D. Kalpana, B. Sekhar, dan J. Kaiser. 2009. Probiotics as complementary therapy for hypercholesterolemia. Biology and Medicine. 1 (4): $\operatorname{Rev} 4$.

Sutama, I.N.S. 2009. Daun pepaya dalam ransum menurunkan kolesterol pada serum dan telur ayam. J. Veteriner, 9 (3) : 152-158.

Tanaka, K., B.S. Youn, U. Santoso, S. Ohtani, and M. Sakaida. 1992. Effects of fermented feed products from chub mackerel extract on growth and carcass composition, hepatic lipogenesis and on contents of various lipid fraction in the liver and the thigh muscle of broiler. Anim. Sci. Technol. 63 : 32-37.

Voet, D., J.G. Voet dan C.W. Pratt. 1999. Fundamentals of Biochemistry. Brisbane : John Willey and Sons.

Wahju, J. 1997. Ilmu Nutrisi Unggas. Gajah Mada University Press. Yogyakarta.

Wiradimaja, R. 2007. Dinamika status kolesterol pada puyuh jepang (Coturnix coturnix japonica) yang diberi daun katuk (Sauropus androgynus (L). Merr.) dalam ransum. Diseration on Performanc. Program Pascasarjana. Institut Pertanian Bogor, Bogor.

Yessirita, N., H. Abbas., Y. Heryandi dan A. Dharma. 2012. Effect of dose and time of leaf lamtoro (leucaena leucocephala) fermentation with Bacillus laterosporus to dry matter, crude protein and crude fiber. Proceeding in International Seminar, The $1^{\text {st }}$ Indonesian Poultry Science Seminar on September $11-12$, p: 367-372. Faculty of Animal Science, University of Andalas, Padang, West Sumatera, Indonesia, in Conjunction with WPSA Indonesia Branch.

Yessirita, N., H. Abbas., Y. Heryandi dan A. Dharma. 2013. The effect of leucaena leaf meal (Leucaena leucochepala) fermented by Bacillus laterosporus and Trichoderma viride in the ration on Performance of Pitalah ducks. Pak. J. Nutr., 12(7): 678-682.

Yuniastuti, A. 2002. Efek pakan berserat pada ransum ayam terhadap kadar lemak dan kolesterol daging ayam broiler. Jurnal Ilmiah Sainteks IX (3): 175-183. 